\title{
OS PROBLEMAS ENFRENTADOS NO COTIDIANO DAS NAVEGAÇÕES PORTUGUESAS DA CARREIRA DA ÍNDIA: FATOR DEABANDONO GRADUAL DA ROTA DAS ESPECIARIAS
}

\author{
Fábio Pestana Ramos \\ Depto. de Filosofia-FFLCH/USP
}

\begin{abstract}
RESUMO: O artigo pretende tratar da descrição de alguns aspectos do cotidiano das navegações portuguesas da Carreira da Índia, mostrando de forma implícita que este foi um dos fatores responsáveis pelo abandono gradual desta rota em beneficio do incremento da Carreira do Brasil.
\end{abstract}

ABSTRACT: The article intends to deal with the description of some aspects of the everyday's life in the Portuguese navigations at the Carreira da Índia. It will be argued that these were some of the factors that were responsible for the gradual abandonment of this route, favouring the increment of the Carreira do Brasil.

PALAVRAS-CHAVE: Portugal, Navegação, Cotidiano, Naufrágios, Morte.

KEYWORDS: Portugal, Navigation, Quotidian, Shipwrecks, Death.

Devido a limitação do espaço, o presente artigo pretende mostrar alguns aspectos referentes ao cotidiano da Carreira da Índia, ou se preferirem da rota da Índia, inaugurada em 1497 pela viagem de Vasco da Gama. Através da abertura desta rota, Portugal deixa de ser mero ponto de passagem do comércio de especiarias, antes dominado pelas cidades italianas de Gênova, Veneza e Florença, para ocupar um papel de destaque no cenário internacional. No entanto devido a uma série de obstáculos, entre os quais se incluem o alto índice de naufrágios e o próprio cotidiano da Carreira da Índia, gradualmente Portugal abandona os investimentos nesta rota para entregarse a exploração colonial do Brasil, perdendo pouco a pouco sua importância no cenário internacional.

Estado Pobre, desde o início Portugal recorreu a investidores estrangeiros, entre os quais estavam incluídos muitos florentinos, e aos empréstimos inter- 
nos obtidos junto a judeus portugueses, que eram pagos pela Coroa quase sempre em espécie. Para os investidores, a Carreira da Índia representava um excelente negócio, embora muito arriscado e de resgate somente a longo prazo. Porém, com o passar dos anos, devido a uma série de fatores, incluindo-se aí a escassez de mão de obra qualificada, que cada vez mais preferia embarcar para o Brasil do que para a Índia, o retorno financeiro começou a tornar-se cada vez menor, fazendo com que os investimentos fossem concentrados na Carreira do Brasil, investimento de retorno quase certo, em detrimento da Carreira da Índia.

Examinaremos aqui justamente alguns aspectos do cotidiano observado a bordo das embarcações das armadas da Índia, que fizeram com que a mão de obra qualificada escasseasse, contribuindo para o aumento do número de naufrágios, e consequentemente para a diminuição dos lucros com o comércio de especiarias. Ou seja, o cotidiano da Carreira da Índia enquanto um dos fatores que de forma indireta influíram em seu abandono gradual.

Um primeiro obstáculo integrante do cotidiano desta Carreira diz respeito à questão da alimentação. A escassez de alimentos em Portugal terminava refletindo-se a bordo das embarcações portuguesas, geralmente abastecidas para enfrentarem cinco meses de viagem em alto mar, quando na verdade a viagem levava no mínimo sete meses. Além do que, os alimentos acabavam se deteriorando ao longo da viagem devido ao tempo e as condições de armazenamento precárias, sendo a fome companheira constante e inseparável dos navegantes portugueses. Em casos extremos muitas embarcações foram obrigadas a recorrerem aos muitos ratos que infestavam o navio como única forma de sobreviver. A respeito desta questão, dada sua complexidade, poderíamos escrever um artigo que tratasse exclusivamente dela, no entanto, como já dissemos não o faremos aqui por uma questão de espaço disponível.
Não podemos detalhar esta questão é verdade, mas também não podemos deixar de dizer que as embarcações da Carreira da Índia, por uma questão técnica envolvendo o regime dos ventos e as correntes marítimas, estavam obrigadas a passar a maior parte do percurso de Lisboa à Índia, principalmente a ida, em alto mar, sem a possibilidade de reabastecer, o que mantinha as embarcações isoladas em um mundo a parte, dependendo única e exclusivamente dos recursos com que haviam partido. Exatamente por este motivo a ração diária de alimentos era sempre racionada e insuficiente, deixando os tripulantes das embarcações portuguesas em um estado contínuo de fraqueza física, e luta diária pela sobrevivência, muito embora certos indivíduos de condição social mais elevada, tais como fidalgos e oficiais, tivessem sempre regalias que lhes permitiam não compartilhar do destino da maioria, usufruindo de alimentos de melhor qualidade e em maior quantidade.

\section{I - As acomodações a bordo}

Além das privações alimentares por que passavam os navegantes da Carreira da Índia, as próprias acomodações a bordo das embarcações constituíam um grande obstáculo. No ambiente insalubre dos navios, que ficavam meses no mar sem ver sinal de terra a vista, dominavam o desconforto e o constrangimento, muito embora o grau deste desconforto estivesse intimamente ligado à condição social do indivíduo.

O capitão da embarcação, por exemplo, tinha direito a uma camara só sua, com varanda, de mais de "uma braça"1, o que equivale a dizer, um quarto de pelo menos 2,2m de comprimento; possuindo o pi-

1 "Relatório do Almirante João Pereira Corte Real, datado de 12 de setembro de 1619, sobre as naus da Carreira da Índia, ao Rei” In: BARCELLOS, 1988, p. 23. 
loto e o mestre, "cada um um camarote dos da rabada da nau" a fim de vigiar a "mezena" (vela do mastro de ré da embarcação); já o "meirinho, tonoeiro, e os dois dispenseiros", dormiam na mesma "camara", que ficava nas "bandas do corredor que vae da tolda dos bombardeiros para o corpo da nau", tendo direito cada um a um "catre", ou seja, a uma cama de viagem.

Já por sua vez, "os marinheiros" eram acomodados no "castelo da prôa", todos na mesma "camara", cada um em um dos "catres", com direito a uma "arca para suas miudezas" que era alojada abaixo do catre inferior; enquanto os grumetes dormiam no convés próximo aos "amantilhos (cabo que sustenta as vergas) e as curvas d'ante a ré dos amantilhos" ${ }^{*}$, local também destinado para o alojamento dos víveres reservados aos doentes.

De qualquer forma, fosse qual fosse o tamanho das acomodações, estas eram sempre desconfortáveis e até mesmo prejudiciais à saúde dos fisicamente mais fracos. O que fazia com que os indivíduos, independente de sua condição social, e portanto de seus privilégios, pensassem duas vezes antes de embarcar na Carreira da Índia, e o que levava muitos a terminarem optando por embarcar na Carreira do Brasil, e isto por ser o tempo de percurso significativamente mais curto, e por conseqüência mais suportável o desconforto a ser enfrentado a bordo.

A questão do conforto somada a outros fatores, teria sido um dos grandes responsáveis pela falta de voluntários para a Carreira da Índia, o que teria feito com que Coroa Portuguesa fizesse cada vez mais uso dos degredados, principalmente, entre a tripulação desta Carreira, enquanto por sua vez o número de voluntários para a Carreira do Brasil aumentava ano a ano. Esta evasão explica-se facilmente pelo fato de

\footnotetext{
2 Idem, Ibid, p. 22

${ }^{3}$ Idem, Ibid, p. 24.

${ }^{4}$ Idem, Ibid.
}

uma viagem a Índia durar cerca de um ano, em oposição às quatro semanas, e às vezes bem menos do que isto, de viagem de Lisboa ao Brasil.

A respeito do desconforto abordo das embarcações da Carreira da Índia, escreveu o italiano Sassetti, "de Cochin, a 27 de janeiro de 1580, ao seu amigo Piero Vittori” que havia ficado em Florença: "Se reflectisse nos sete meses de navegação que será preciso passar, em regime de biscoitos e de água salobra, enfiado num estreito espaço no meio de oitocentas a novecentas pessoas, atormentado pela fome, pela sede, pelo enjôo, pelo desconforto, haveria poucos voluntários para irem à Índia" (BRAUDEL, 1983, vol. 1, p. 420).

Não temos como saber o espaço disponível por metro quadrado por passageiro em cada embarcação portuguesa, até mesmo pelo fato de não haver uma embarcação de mesmo tipo construída exatamente igual a outra, por ser este um trabalho artesanal. No entanto, caso levássemos em conta que uma grande caravela de " 180 " toneladas e três cobertas, possuindo "16" metros comprimento por cerca de " 8 " (FONSECA, 1978, p. 272) metros de largura, ou seja, $128 \mathrm{~m}^{2}$ por coberta, levava além de sua carga, uma média de 500 pessoas entre tripulação, soldados e passageiros e considerando uma coberta como destinada exclusivamente ao transporte de passageiros, teríamos cerca de pouco mais de $25 \mathrm{~cm}^{2}$ destinados a cada pessoa. Caso considerássemos também como espaço disponível ao transporte de passageiros, o convés, teríamos então pouco mais de $50 \mathrm{~cm}^{2}$ por pessoa, mesmo assim teríamos ainda um pequeno e restrito espaço destinado a cada pessoa a bordo.

Considerando estes números, não como exatos, mas sim como aproximados, podemos imaginar o desconforto enfrentado pelos que se aventuravam nas embarcações da Carreira da Índia, bem como o constrangimento causado pela falta de higiene que devia imperar neste ambiente. Além disto, podemos supor que a falta de espaço era um grande incentivador da 
promiscuidade a bordo, e como as mulheres eram poucas e escassas neste ambiente quase exclusivamente masculino, os casos de sodomia deveriam ser muito comuns, porém não cabe aqui discorrer sobre isto, mais adiante o faremos com detalhes, por ora basta saber que cada indivíduo ficava sempre restrito a um pequeno espaço.

Talvez o leitor esteja se questionando, em primeiro lugar, quanto às duas outras cobertas da caravela com a qual chegamos ao número aproximado de metros quadrados por pessoa. Cabe aqui esclarecer que a prioridade de ocupação do espaço disponível, em toda e qualquer embarcação portuguesa da Carreira da Índia, era sempre dominada pelas especiarias, nem mesmo os víveres tinham tanta importância quanto a preciosa carga oriental, tendo sido este excesso de carga um dos grandes responsáveis pelo alto índice de naufrágios nas armadas da Índia.

Em segundo lugar, provavelmente o leitor deve estar questionando se podemos considerar, a partir da exemplificação de uma caravela, o número aproximado de metros quadrados por pessoa a que chegamos, como sendo válido também para uma nau, embarcação bem mais espaçosa, e que talvez tivesse maior espaço por metro quadrado por pessoa. Neste tocante cabe dizer que quanto maior a embarcação, maior o número de indivíduos e carga embarcada, ou seja, proporcionalmente o espaço por metros quadrados devia ficar sempre em torno de pouco mais de 50 centímetros por pessoa, ou se preferirem em torno de 2 passageiros por metro quadrado. Somente a título de exemplo, "em uma nau de 800 toneladas embarcavam, tripulação, soldados e funcionários, novecentas pessoas, às vezes mais. Imagine-se o aperto, a carência de asseio, (e) a desordem" (AZEVEDO, 1988, p. 156).

Como afirmam Francisco Contente Domingues e Inácio Guerreiro, em seu artigo "A vida a bordo na Carreira da Índia”, "o quotidiano das centenas de homens (e por vezes algumas mulheres) que deman- davam o Oriente, em naus e galeões superlotados, em condições deficientes de alojamento e higiene; mal alimentados e mal protegidos da doença e do frio, por vezes resistindo com dificuldade à longa monotonia dos dias sempre iguais durante meses seguidos", era sempre movido pela incerteza. "Embarcar, bem mais do que já sucedia na vivência quotidiana do homem de Quinhentos, era um passo directo para os braços da providência. Ela decidia depois dos destinos de cada um e de todos" (DOMINGUES, p. 188). O que nos leva a considerar que neste ambiente desconfortável e apertado deviam proliferar tantas, ou até mais, doenças do que no continente europeu, dominado pelas pestes.

FORMA DAS CUBERTAS DE HŨA NAO. GAZALHADOS DELLL.
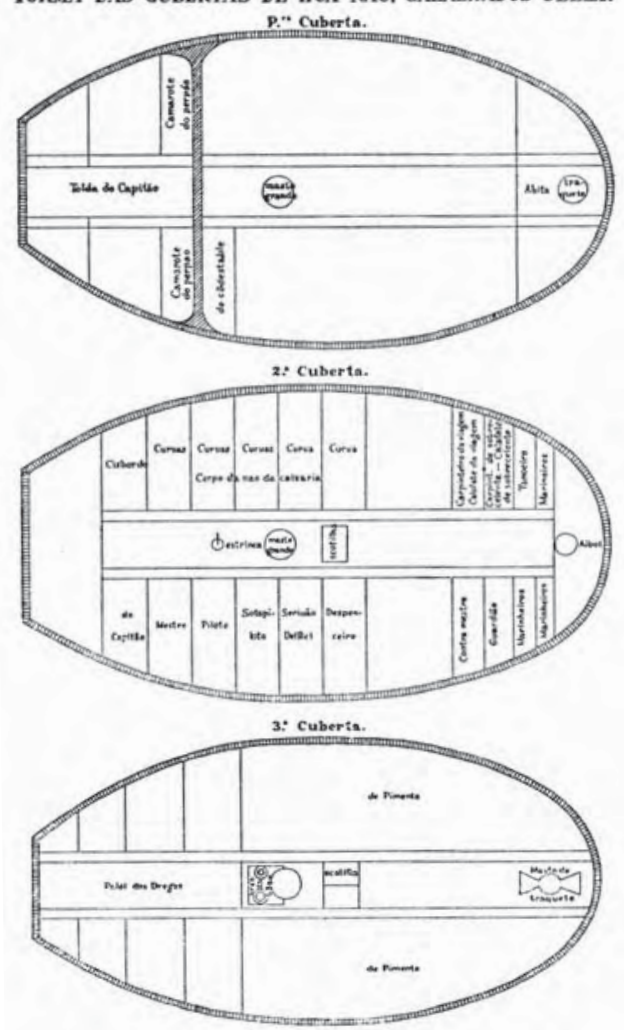

Plano de uma nau de três cobertas, onde se pode observar a disposição dos alojamentos na segunda coberta, o convés definido como primeira coberta, e a terceira coberta destinada ao transporte da carga, presente In: SÉRGIO, 1958, p. 214. 


\section{II - A Peste}

No século XVI, Portugal, hoje com dez milhões de habitantes, era um pais de cerca de "um milhão" (BRAUDEL, 1983, vol. 1, p. 441) de habitantes, e apesar de, como bem salientou o grande historiador francês Fernand Braudel, em seu $O$ mediterrâneo e o mundo mediterrânico na época de Felipe II, a comunicação ser lenta entre os diversos países europeus, até mesmo pela diversidade de barreiras naturais, a penetração das pestes era sempre rápida e implacável.

A primeira grande epidemia que atingiu Portugal data de 1348, quando "toda a Europa foi varrida por uma terrível epidemia de peste negra". Nesta ocasião "grande parte da população, em algumas regiões mais da metade", foi praticamente dizimada. A partir de então, como em vários outros pontos da Europa, diversas regiões do país foram constantemente atacadas pela peste, que durava em cada local por que passava um "espaço de três meses", e que constituída das mais variadas doenças causava entre outros sintomas "levações (inchaços) que tinham (os indivíduos) nas virilhas e sob os braços" (SARAIVA, 1995, p. 101).

À peste, nem mesmo os indivíduos de condição social mais elevada podiam escapar. Durante o reinado de D. Duarte (1433-1438), por exemplo, "ao tempo" em que "começava a morrer-se de peste" em Lisboa, "o rei mudou para Santarém”, porém a peste o perseguiu forçando-o a mudar-se para "Leiria", e mais tarde pelo mesmo motivo para "Évora", não obstante terminou sendo tudo em vão, pois "no final de agosto de 1438, a peste que grassava em Évora obrigou a Corte a abandonar a cidade". "D. Duarte foi para Tomar, onde adoeceu de febre mortal", e mesmo estando cercado de "físicos e homens de boa vida para" cuidarem de sua recuperação, faleceu de peste em "9 de setembro" de 1438, "nos passos do convento" de Tomar, "para onde o haviam levado" (MORENO, 1995, p. 130), colocando fim a um curto e desastroso reinado que incluiu a humilhante derrota militar de Tânger e o aprisionamento do Infante D. Henrique, seu irmão (não confundir com D. Henrique, o navegador), e sua respectiva morte no cativeiro.

Levando em conta que a peste era algo comum e corriqueiro na Europa do século XVI, podemos conjecturar que talvez muitas das doenças a bordo das embarcações da Carreira da Índia fossem trazidas pelos passageiros ou tripulantes da Europa, e não adquiridas a bordo, muito embora deva-se ressaltar que a inanição teria sido a responsável por outra grande parte destas doenças, ou pelo menos pelo agravamento do quadro de doenças a bordo.

De qualquer modo, o que na época se chamava de peste era um verdadeiro leque das mais diversas doenças, cujas causas em sua maioria eram desconhecidas. A peste negra propriamente dita, por exemplo, era uma doença causada pelo bacilo de Yersin (Pasteurella pestis), transmitida ao homem por pulgas que picavam ratos doentes, doença esta que devia ser bem comum nas embarcações portuguesas, pois como sabemos estas eram infestadas de ratos. Somente a peste negra possuía, como ainda possui, diversas variações, tais como: a peste bubônica, que fica incubada cerca de doze dias antes que os primeiros sintomas apareçam; a peste pneumônica, com sintomas de broncopneumonia; e a peste septicêmica, que causa febre violenta, delírios, hemorragias cutâneas e nas mucosas, e morte em alguns dias.

Exatamente por este motivo não podemos descartar a hipótese de que o que se denomiva peste, fossem na verdade doenças tais como febre tifóide, varíola, sarampo, rubéola, escarlatina, caxumba, coqueluche, tétano, tuberculose, difteria, cólera, lepra, ou mesmo uma simples disenteria. Todas doenças que incomodavam os europeus desde a antigüidade, das quais pouco se conhecia, e para as quais não havia cura. Além disto deviam ser igualmente comuns, a bordo das embarcações portuguesas, as doenças tropicais incubadas no oriente pelos passageiros e tripulantes, que afloravam ao longo da viagem de volta ao Reino. 
Apesar da grande variedade de doenças inseridas no cotidiano dos navegantes portugueses, com exceção de embarcações que transportavam vice-reis e personalidades de destaque, "há poucas notícias sobre a presença e intervenção de médicos a bordo". Esta função era via de regra exercida pelo barbeiro que "actuava como sangrador", enquanto os padres acudiam como enfermeiros. Algumas fontes dão conta que "pola menhã, depois" de encomendar os mortos "a Deus, hia o padre" com "o barbeiro por toda a nao" visitar "os enfermos" (DOMINGUES, p. 210). Caso os pacientes tivessem febre, frenesis, inchaço, ou até mesmo uma loucura súbita, a sangria era aplicada como único remédio capaz de trazer a cura, de forma que seriam muito mais estas sangrias do que as doenças propriamente ditas a quem caberia a verdadeira responsabilidade por muitas das mortes a bordo.

De qualquer modo, "a morte (era) um sonho eterno, um espanto de ricos, um apartamento de amigos, uma incerta peregrinação, um ladrão do homem, um fim dos que vivem, e um princípio dos que morreram"5 a bordo das embarcações da Carreira da Índia. E apesar de algumas fontes afirmarem que só morriam "nestas naus" os "mesquinhos, que (vinham) no convés mortos de fome, e despidos ao sol, e chuva, e serenos da noite" ${ }^{6}$, nem mesmo os padres que serviam de enfermeiros escapavam ao destino do resto dos tripulantes e passageiros das embarcações portuguesas, como por exemplo no caso da viagem feita a Índia pela nau São Francisco em 1596, quando "todos oito" padres da "Companhia" de Jesus, que serviam de en-

5 "Relação do naufrágio da Nao S. Thomé na terra dos fumos, no ano de 1589, relatado por Diogo do Couto" In: BRITO, 1971, p.546.

6 "Relação do Naufrágio da Nao Santiago no ano de 1585, relatado por Manoel Godinho Cardozo" In: BRITO,1971, p. 439. fermeiros a "toda a gente", com exceção de não mais que "cinco, de quatrocentas e sessenta pessoas" que adoeceram a bordo, juntos cairam também doentes gravemente ${ }^{7}$.

Quando a peste atacava, não distinguia o rico do pobre, o capitão do marinheiro, ou mesmo o vice-rei do simples grumete. É bem verdade, como já afirmamos implicitamente, que as naus que transportavam figuras de destaque quase sempre possuíam um médico a bordo, e portanto melhores condições para a erradicação das doenças. Porém grande parte, mesmo dos médicos, em "sua maioria judeus" 8 radicados em Portugal, valia-se da sangria como principal fonte de cura, o que só agravava a situação dos doentes. De fato as constantes doenças a bordo da Carreira da Índia eram impiedosas, não distinguindo a condição social dos indivíduos, muito embora, por estarem melhor alimentados, os indivíduos de classe social mais alta corressem menos risco de contrair doenças a bordo.

Um relato anônimo de um viajante que passou por Portugal no século XVIII, publicado em Paris no ano de 1730, do qual alguns historiadores suspeitam tratar-se na verdade de um relato de um espião francês, ou de um grupo de espiões, dá conta que ainda nesta época "os médicos do país (eram) tidos, no consenso geral, como muito hábeis; contudo (...) extremamente pródigos do sangue dos doentes", quase não conhecendo "outro tratamento que não seja o das

7 "Relação da viagem da Nao S. Francisco NO ANO DE 1596, Relatado pelo Padre Gaspar Affonso" In: BRITO, 1971, p. 647.

8 "Description de la ville de Lisbonne oú l'on trait de la Cour, de Portugal, \& des Moeurs des des Habitans; du gouvernement, des revenus du Roi, \& de les forces par mer e par terre; des Colonies Portugaises \& du commerce de cette capitale - A Paris - Chez Pierre Prault, Quay de Gesfres, au Paradis - MDCCXXX” In: CHAVES, 1989, p. 62. 
sangrias. Nas doenças correntes (começavam) por ordenar uma meia-dúzia de sangrias e quando o mal se (tornava) teimoso eles (elevavam) o tratamento até quinze ou vinte sangrias e de tal maneira que o melhor que (poderia) acontecer ao doente (era) ficar com uma anemia de que (teria) de se recuperar".

Através deste relato, que reflete a ignorância em que se encontrava a medicina portuguesa em pleno século XVIII, quando se poderia presumir um avanço da medicina comparativamente às técnicas observadas no século XVI e XVII, podemos notar que o fato de a embarcação estar assistida ou não por um médico pouca diferença fazia no sistema de tratamento adotado. Médico, barbeiro ou padre, tanto em terra como em mar, utilizavam largamente métodos arcaicos e equivocados de cura, a medicina estava intimamente relacionada com técnicas de curandeirismo medieval.

Um fator a levar em conta quando tratamos de questões relacionadas à saúde a bordo das embarcações, é sem dúvida a questão da higiene. A maior parte das fontes se omite quanto a esta questão, no entanto tudo leva a crer que o ambiente a bordo fosse dos mais insalubres, em primeiro lugar não havia como se lavar, o que fazia com que os indivíduos passassem meses sem banhar-se. Além disso o lixo e os dejetos humanos deviam acumular-se com freqüência. Levando em conta a precariedade do saneamento que imperava nas cidades medievais, tudo realmente nos leva a deduzir que nas embarcações a situação devia ser muito mais grave, afinal no reduzido espaço de 50 centímetros quadrados por pessoa, manter uma higiene adequada para os padrões atuais era praticamente impossível.

Considerando este fator, podemos facilmente perceber que a questão da má higiene a bordo era também responsável, de forma indireta, por grande núme-

\footnotetext{
${ }^{9}$ Idem, Ibid, p. 61.
}

ro de doenças entre os navegantes portugueses, à medida que, como conseqüência de uma higiene deficiente, acabavam sendo contaminados os escassos alimentos e a água destinada ao consumo da tripulação e dos passageiros, entre outros microorganismos, por exemplo, pelos famosos poliformes fecais, causa entre outras doenças das constantes diarréias a bordo das embarcações.

A dureza do cotidiano das embarcações das armadas da Índia, cercado pela fome e pelas doenças, criava um ambiente de "pressão psicológica constante" (DOMINGUES, p. 218) extremamente propício à eclosão de conflitos de ordem social. Estes conflitos terminavam sempre estourando em forma de motins, que apesar de raros, representavam um perigo constante, e muito temido pela Coroa Portuguesa, e por conseqüência pelos oficiais das embarcações e os respectivos fidalgos que seguiam como passageiros, que eram sempre as primeiras vítimas dos amotinados.

\section{III - Os motins}

Em meio à falta de conforto, à fome, à sede, ao medo das intempéries e dos acidentes, os marinheiros e grumetes eram submetidos a uma rígida disciplina militar. Na verdade, o tratamento especial dispensado a fidalgos e oficiais proporcionava um padrão de qualidade de vida em muito superior ao destinado à arraia miúda. Esta reprodução da estratificação social portuguesa em mar gerava um ambiente de grande pressão psicológica, no qual o abismo que separava fidalgos do restante dos tripulantes era causa constante de revolta. Não temos relatos que tratem especificamente de motins a bordo das embarcações da Carreira da Índia, mas todos os indícios levam a crer que eram extremamente comuns.

Em um relatório apresentado a Felipe II da Espanha, pois nesta época Portugal encontrava-se sob o jugo Espanhol, datado de 12 de setembro de 1619, redigido pelo Almirante português, João Pereira 
Côrte Real, recomenda-se que o capitão de cada embarcação tenha "dentro (de sua) camara duas peças d'artilharia que nunca abaterá", e que o meirinho tenha seu "catre" de fronte ao armário "das armas que d'ali hade vigiar"10. O que por si demostra o ambiente de permanente tensão a bordo das embarcações portuguesas, uma vez que os capitães estavam obrigados a manterem-se sempre alertas contra o perigo de motim a bordo.

Este mesmo relatório recomenda ainda que "toda pessoa que fazer motim e se alevanta muito ou que em qualquer acontecimento desobedecer ou não favorecer á parte do seu capitão não vença soldo para o que trará sua verba no livro do escrivão e que nenhum marinheiro possa ser outra vez admitido a outra viagem sem apresentar certidão do capitão" ${ }^{11}$. Diante da constante ameaça de motim a bordo, a disciplina rígida tentava agir como fator inibidor, muito embora algumas vezes não conseguisse evitar os conflitos sociais e pessoais entre fidalgos e marinheiros, e mesmo entre os próprios marujos. É curioso notar que muitos homens embarcavam na Carreira da Índia com a única intenção de "vingar-se de algum desafeto fugido para a Índia” (MICELI, 1994, p. 175), prática muito comum na época.

A disciplina era rígida, e precisava ser assim, pois como dão conta alguns relatos, o caráter dos homens que embarcavam rumo a Índia era sempre duvidoso, isto sem contar o fato que toda embarcação contava sempre entre seus tripulantes ou passageiros com grande número de degredados, muitos por motivos políticos é verdade, mas também outros por crimes comuns como assassinato ou roubo. Em terra, já no século

10 "Relatório do Almirante João Pereira Corte Real, datado de 12 de setembro de 1619, sobre as naus da Carreira da Índia, ao Rei de Espanha" In: BARCELLOS, 1988, p. 23.

11 Idem, Ibid, p. 25
XVIII, os portuguesas tinham fama de não ter nenhum "escrúpulo (em) matar um inimigo a traição" ${ }^{22}$. No mar, em uma época anterior, e em circunstâncias onde a violência era um fato corriqueiro, tudo leva a crer que esta situação fosse em muito intensificada.

Como bem salientou Antônio Sérgio, organizador de uma esplêndida coletânea de relatos de naufrágios, "é quando os homens tombam nos abismos da desgraça e da miséria, despojados de todos os bens e inexoravelmente postos frente a frente da morte, que eles se mostram a nu e se revelam em plena grandeza ou baixeza da alma" (SÉRGIO, 1958, p. 281). Nem sempre os motins observados a bordo da Carreira da Índia eram de ordem coletiva, muitas vezes eles eram individuais, e motivados não por questões de ordem social, mas sim pelo medo da morte.

Em casos de perigo eminente, como por exemplo quando a Nau São Paulo estava prestes a naufragar em 1561, o capitão precisava recorrer a "uma espada nua"13 para fazer cumprir suas ordens. Em outros casos o motivo da discórdia era a divergência de opiniões entre algum inexperiente piloto e um experimentado marujo, ou ainda a presença de uma mulher a bordo, o que causava sempre um grande alvoroço entre os homens, que isolados por meses a fio, estavam constantemente sedentos pela companhia feminina. Neste ambiente conturbado, a coação, a intimidação pela violência era o único fator capaz de manter a disciplina, a ameaça de "cortar a cabeça" ${ }^{14}$ a quem

12 "Carta escrita de Lisboa pelo viajante César de Saussure, datada de 28 de janeiro de 1730" In: CHAVES, 1989, p. 272 .

13 BRITO, Bernardo Gomes de. História TrágicoMarítima. Lisboa, Edições Afrodite, 1971, fac-símile da edição original de 1735 , p. 343.

14 Idem, Ibid, p. 328. 
desobedecesse uma ordem de um superior era um recurso usado com freqüência.

Visando manter um controle apertado sobre a tripulação, a fim de evitar motins e mesmo conflitos de ordem pessoal entre a arraia miúda, os oficiais terminaram estabelecendo uma verdadeira rede "de espionagem e delação" a bordo. Era praxe escolher ao início de cada viagem "dois acusadores e síndicos de cada sorte de gente (...) para que o marinheiro acusasse aos marinheiros, e o soldado aos soldados, e isto sem saber os outros quem estes eram", de forma a manterem sempre informados, sobre qualquer conflito a bordo, os oficiais da embarcação, para que pudessem inibir qualquer tentativa de motim antes mesmo que esta se iniciasse. "Proibidas as atividades de prazer e lazer a bordo, restava preencher os longos meses de travessias com atividades que, ao ocupar corpos e mentes, pudessem distrair das brigas cotidianas" (MICELI, 1994, p. 175) a arraia miúda. Desta tarefa se encarregaram os religiosos embarcados na Carreira da Índia que através das comemorações religiosas, faziam procissões e representações da vida dos Santos, procurando assim canalizar a atenção da tripulação para uma vida espiritual austera.

"Independentemente de serem representadas por ocasião de qualquer festividade religiosa particular, e de terem como fim último um propósito espiritual (doutrinação e moralização dos passageiros e tripulantes), as peças teatrais eram o único espectáculo organizado a bordo" (DOMINGUES, p. 218), e também a única forma de lazer permitida. A preparação destes espetáculos ocupava os participantes por dias a fio, centralizando o excedente da tripulação nesta tarefa, evitando assim que houvesse tempo para a preparação de motins, ou mesmo que a arraia miúda tivesse sequer a oportunidade de parar para pensar nesta possibilidade.

A encenação destas peças era sempre rudimentar, e algumas vezes se confundiam com verdadeiras procissões religiosas que seguiam por toda a embar- cação. Além disto os tripulantes procuravam se distrair através de jogos de azar que muitas vezes terminavam em briga e que apesar de tolerados por alguns religiosos, certamente eram vigiados de perto pelos oficiais, por meio do sistema de delações.

Prática comum entre as marinhas de vários países, nas mais diferentes épocas, os tripulantes indisciplinados eram punidos com açoites públicos, e acorrentados ao porão dos navios, postos a ferros como se dizia popularmente. O cotidiano dos homens embarcados na Carreira da Índia era sempre sofrido, o que fazia com que houvesse cada vez menos voluntários dispostos a embarcar, e isto não só pelo dureza do cotidiano, mas também pelo elevado risco de naufrágio.

\section{IV - Os Naufrágios}

Devido à limitação de espaço, não será possível fazer aqui uma descrição detalhada a cerca da questão dos naufrágios. No entanto podemos afirmar que entre 1497 e 1653, o índice de naufrágios observados na Carreira da Índia foi da ordem de cerca de $19 \%$ das embarcações partidas de Lisboa. O prejuízo acumulado ao longo deste período foi de tal ordem, que a partir de 1653, época de uma crise generalizada na Europa, a Carreira da Índia passa de principal rota para um segundo plano, cedendo lugar à Carreira do Brasil, que por representar um investimento mais rápido e seguro, desde início do século XVII, gradualmente, obtém cada vez mais um número maior de investidores e voluntários dispostos a embarcar em seus navios.

Segundo dados levantados por nós, cerca de um a cada cinco navios partidos de Lisboa, entre 1497 e 1653 , naufragou. O que eqüivale a dizer que pelo menos uma a cada dez pessoas embarcadas falecia vítima de naufrágio. As causas destes naufrágios eram as mais diversas, sendo que algumas vezes, e não raro, cada naufrágio tinha não apenas uma única causa, como era uma verdadeira somatória de fatores. Entre 
TABELA I

Naufrágios na Carreira da Índia (1497-1653):

\begin{tabular}{ccccc}
\hline Período & Partidas & Arribamentos & Naufrágios & $\begin{array}{c}\% \\
\text { Naufrágios }\end{array}$ \\
\hline $1497-1499$ & 4 & 0 & 1 & 25,0 \\
$1500-1509$ & 144 & 5 & 19 & 13,1 \\
$1510-1519$ & 98 & 0 & 9 & 9,18 \\
$1520-1529$ & 83 & 2 & 15 & 18,07 \\
$1530-1539$ & 88 & 3 & 6 & 6,82 \\
$1540-1549$ & 58 & 3 & 6 & 10,35 \\
$1550-1559$ & 54 & 5 & 13 & 24,07 \\
$1560-1569$ & 42 & 4 & 6 & 14,29 \\
$1570-1579$ & 50 & 0 & 5 & 10,0 \\
$1580-1589$ & 54 & 9 & 9 & 16,67 \\
$1590-1599$ & 55 & 7 & 24 & 43,64 \\
$1600-1609$ & 74 & 9 & 31 & 41,89 \\
$1610-1619$ & 51 & 7 & 12 & 23,53 \\
$1620-1629$ & 70 & 9 & 23 & 32,86 \\
$1630-1639$ & 42 & 5 & 5 & 11,90 \\
$1640-1649$ & 40 & 1 & 9 & 22,50 \\
$1650-1653$ & 15 & 0 & 2 & 13,33 \\
Total & $\mathbf{1 0 2 2}$ & $\mathbf{6 9}$ & $\mathbf{1 9 5}$ & $\mathbf{1 9 , 0 8}$ \\
\hline
\end{tabular}

Fonte: Levantamento realizado a partir do confronto de informações entre os "Navios da Carreira da Índia", códice anônimo da British Libray, e a relação dos "Governadores da Índia", escrita em Goa pelo Padre Manuel Xavier; ambas presentes. In: ALBUQUERQUE, Luís de (org.). Relações da Carreira da Índia. Lisboa, Alfa, 1989.

\section{Gráfico de partidas e naufrágios}

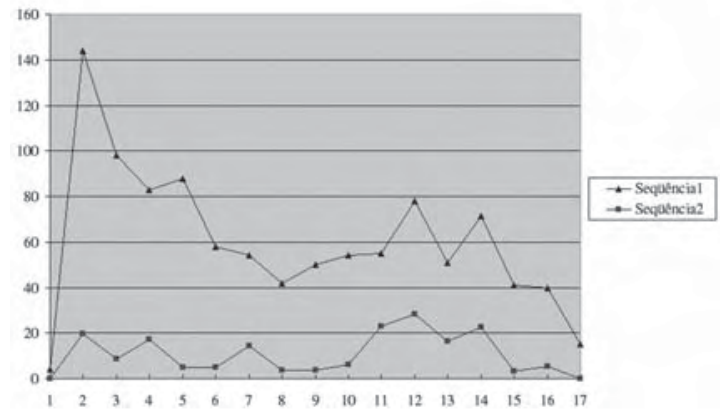

as principais causas estavam o mau tempo, o desconhecimento do território e da profundidade das águas, o desconhecimento do regime dos ventos e das correntes marítimas, a imperícia do piloto, o excesso de carga, o desgaste natural das embarcações, doenças que dizimavam a tripulação impossibilitando a continuidade da viagem, e ataques piratas seguidos da queima da embarcação.

Na verdade a causa de um naufrágio estava associada a dois ou mais fatores agrupados. Como, por exemplo, no caso de um naufrágio causado por uma tempestade, que tanto poderia ter sido causado pelo mau tempo em si, como pela incapacidade, inexperiência, ou desconhecimento do território e da profundidade das águas, por parte do piloto, impossibilitando-o de conduzir a embarcação sob mau tempo. Ou mesmo pela embarcação estar de tal modo carregada, ou envelhecida pelo tempo, que não podia resistir à tempestade. Ou então com um número tão grande de enfermos a bordo, de modo que não haveria tripulação suficiente para conduzir a embarcação durante uma tempestade.

De qualquer forma, fosse qual fosse a causa do naufrágio, certamente o abandono gradual da Carreira da Índia em benefício da Carreira do Brasil, pela mão de obra qualificada, devido à segunda representar um padrão de qualidade de vida superior à primeira, contribuiu indiretamente para o aumento do número de naufrágios, que levariam os investidores a transferir seus recursos da rota da Índia para a rota do Brasil, em busca de um investimento mais rápido e seguro. É obvio que a questão é bem mais complexa do que isto, mas em termos gerais podemos afirmar que o cotidiano da Carreira da Índia foi um dos fatores responsáveis pelo seu declínio.

\section{V - O cotidiano das mulheres}

Para encerrar este artigo, resta-nos examinar as dificuldades enfrentadas pelas mulheres a bordo das em- 
barcações da Carreira da Índia. De fato não poderíamos deixar de tocar neste tema tão pouco explorado e de fundamental importância, à medida que "as mulheres não são apenas parte essencial de qualquer estudo equilibrado de história social, mas ainda, pela sua presença ou ausência (...), são uma bitola indispensável da qualidade e ritmo do progresso social geral, bem como da categoria, prosperidade e ascendência de qualquer homem" (BOXER, 1977, p. 09).

As mulheres portuguesas, descritas sempre pelos relatos dos viajantes estrangeiros que passaram por Portugal, como "muito formosas, bastante cheias", de "pele branca", possuidoras, "em geral" de "lindíssimos olhos e muita vivacidade" 15 , eram raridade nas embarcações da Carreira da Índia. Exatamente por este motivo terminaram sendo muito comuns os casos de sodomia a bordo das embarcações portuguesas, a falta de mulheres levou muitos homens a apelarem ao homossexualismo. Embora a Inquisição tenha tentado em determinados momentos colocar um "freio à sodomia, vício odioso ao qual os portugueses pela sua natureza ardente (eram) demasiadamente inclinados" ${ }^{16}$, um exame do último regimento da inquisição de Goa, datado de 1778 , permite perceber que a lei e a Igreja procuravam fazer vista grossa aos atos de sodomia praticados no além-mar.

Não obstante "no início do século XVI, (...) as ordenações Manuelinas (fixaram) a pena de morte na fogueira para qualquer homem que cometesse o pecado da sodomia - para que de seu corpo não haja memória - e (decretaram) o confisco de bens em favor da

15 "Description de la Ville de Lisbonne où l'on traite de la Cour, de Portugal, de la langue portugaise, \& des mouers des habitans; du governement, des revenus du Roi, \& de les forces par mer \& par terre; des Colonies Portugaises \& du commerce de cette capitale - A Paris - Chez Pierre Prault, Quay de Gesfres, au Paradis - MDCCXXX” In: CHAVES, 1989, p. 59.
Coroa e a inabilitação dos filhos e netos do condenado, pena que seria confirmada nas ordenações Filipinas do século XVII", muito "embora poucos, a rigor, tenham sofrido a pena capital" (VAINFAS, 1997, p. 118). No livro III, "das penas que hão de haver os culpados nos crimes de que se conhece no Santo Ofício"17, no seu título XXI - "dos que cometem o crime nefasto de sodomia"18, é recomendado, "pelos breves de Pio IV, Gregório XIII e declarações de Paulo V", bem como "por cartas do Cardeal Melino" e por "uma provisão do senhor cardeal infante D. Henrique", que se evite a "pena pública" para este tipo de crime, em "razão da infâmia e de se absterem os réus pelo temor dela de virem confessar suas culpas e descobrirem os cúmplices com quem as cometeram" 19 , deixando transparecer que provavelmente além dos marinheiros, estivessem constantemente implicados homens de condição social mais elevada neste tipo de prática, aliás bem mais comum do que se imagina também em terra firme, inclusive em Portugal.

O viajante Charles Fréderic de Merveilleux, médico naturalista que prestou serviço e fez carreira nos exércitos do rei de França, onde atingiu o posto de tenente-coronel, e que serviu esporadicamente ao Rei de Portugal em quatro períodos relativamente curtos, em um de seus relatos de passagem por Portugal, diverte-se com o quadro hilário de uma cena observada dentro da casa de uma respeitada e importante família portuguesa, onde "a dona da casa teimava em querer meter um filho seu numa casa onde ela tinha um tio", ao que seu "marido não consentia, contando dramati-

16 "Memórias instrutivas sobre Portugal, por Charles Fréderic de Merveilleux, 1723-1726” In: CHAVES, 1989, p. 170.

17 "O último regimento da inquisição de Goa, (1778)"

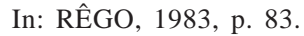

18 Idem, Ibid, p.114

19 Idem, Ibid. 
camente e sem resguardo de conveniências o que ali mesmo lhe havia feito sofrer", mesmo assim "a senhora insistia sobre a promessa que lhe havia feito ao seu querido tio de lhe entregar o filho aos seus cuidados" ${ }^{20}$. O relato prossegue contando que após uma grande discussão, "o garoto" terminou por ser "entregue com toda confiança ao bom velho que tinha tido também debaixo da sua férula o pai do rapaz", dando continuidade à saga homossexual da família, sendo que alguns anos mais tarde o garoto então crescido ocuparia "na magistratura um cargo elevado" 21.

Segundo este mesmo viajante, os portugueses que haviam estado "em Roma" eram "os mais dados a esse vício", pois só eram mandados a Roma "os desgraçados que haviam abusado de suas irmãs ou próximas parentes na mira de obterem a absolvição ou a dispensa para se casarem" 22 . É obvio que nem todos os portugueses tinham condições de ir a Roma pedir perdão diretamente ao Papa, até mesmo porque este perdão obrigava os penitentes a "sangrarem as bolsas" 23 , o que indica que a prática de sodomia e violação de parentes, e não parentes, devia ser bem comum não só entre os de classe mais alta mas também entre os camponeses.

O fato de ser mandado a Roma ser considerado, no imaginário popular, como a perdição certa do jovem que para lá fosse, a medida que representava uma iniciação ao homossexualismo, terminou fazendo com que o Rei proibisse "aos seus súditos de irem a Roma", o que fez com que diminuísse "o número dos incestuosos porque os portugueses têm horror a morrer sem absolvição, uma vez que não (há) no reino

20 "Memórias instrutivas sobre Portugal, por Charles Fréderic de Mervelleux, 1723-1726” In: CHAVES, 1989, p. 172.

${ }^{21}$ Idem, Ibid.

${ }^{22}$ Idem, Ibid, p. 171.

${ }^{23}$ Idem, Ibid. quem lha possa dar (absolvição) para pecados dessa natureza" ${ }^{24}$.

Em terra ou em mar, em Lisboa ou em Goa, as penas da inquisição para a sodomia eram consideradas pelos estrangeiros como muito brandas, pois enquanto "em França, na Suíça, na Alemanha, etc., (queimam-se) sem remissão os que praticam crimes contra a natureza; em Portugal, a inquisição não os (faz) queimar senão depois de reincidirem", sendo que "muitos eclesiásticos" defendiam a isenção "de inquisições" para aqueles que praticassem sodomia, ou pelo menos que "não (tivessem) castigo severo", e isto por ser "sabido que em certas casas" eclesiásticas "onde se (instruíam) os jovens nas ciências e na piedade se lhes (ensinavam) mais relaxações do que declinações latinas"25.

Enquanto alguns Padres defendiam "nos diversos tribunais" os atos de homossexualismo, por serem eles mesmos adeptos desta prática, sobre pretexto de "lhes ser doloroso terem de condenar desgraçadas vítimas desse vício ao mesmo tempo que não (poderiam) esquecer as palavras do Salvador: Que aquele que não pecou the atire a primeira pedra" ${ }^{26}$; o último regimento da inquisição de Goa recomenda que os culpados por sodomia que se apresentassem "voluntariamente", caso não houvesse "testemunhas", "depois de tomadas suas confissões", e advertidos "para não cometerem mais tal crime, porque, reincidindo nele, (seriam) tratados com grande rigor", que fossem absolvidos "não (sendo) condenados em pena alguma" ${ }^{27}$.

Mesmo no caso de haver testemunhas dos atos de sodomia, "nem por isso" os culpados eram castigados "com pena pública", tinham "porém alguma pena e

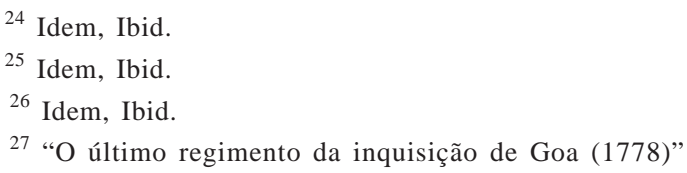
In: RÊGO, 1983, p. 114. 
penitência ocultas pelas quais se não" viesse ao "conhecimento" público "sua culpa" ${ }^{28}$. Somente no caso dos culpados serem "devassos no crime" ou "publicamente escandaloso(s)" deveriam ser condenados "secretamente em pena de degredo", sendo recomendado na reincidência, no caso de "peões" que fossem açoitados e degredados por dez anos, e no caso de "pessoa qualificada" degredados "por toda a vida" 29

Um fato curioso e ao mesmo tempo estranho, na medida que as mulheres eram sempre minoria, é o de estar previsto como pena a "alguma mulher compreendida neste crime", pelo "grande escândalo e dano que podem resultar de se fazerem mais públicas semelhantes", a pena de degredo "para Macau, por tempo de cinco anos" ${ }^{\text {"30 }}$, não importando se havia testemunhas ou se tratava-se da primeira vez que haviam sido pegas em atos homossexuais. O que indica que ao mesmo tempo em que a igreja e a sociedade toleravam o homossexualismo masculino no além mar, contanto que os implicados fossem discretos, o mesmo não se aplicava ao homossexualismo feminino, sendo ele veementemente condenado.

De qualquer modo, muito embora "a esmagadora maioria dos que deixavam Portugal" terem sido "homens válidos", obrigando os mesmos, devido à falta de mulheres a bordo da Carreira da Índia, a se entregarem a um homossexualismo velado, "um apreciável, embora pequeno número de mulheres" (BOXER, 1977, p. 14) também partiu rumo a Índia. Como podemos imaginar, a bordo das embarcações portuguesas, como em terra entre "os séculos XVI e XVIII", como bem lembrou a Profa. Dra. Mary Lucy Murray Del Priore, referindo-se à realidade enfrentada pelas

\footnotetext{
${ }^{28}$ Idem, Ibid.

${ }^{29}$ Idem, Ibid.

${ }^{30}$ Idem, Ibid, p. 115.
}

mulheres no Brasil Colonial, conceito este perfeitamente aplicável a realidade aqui estudada, "a mulher" foi sempre "vítima constante da dor, do sofrimento, da humilhação e da exploração física, emocional e sexual" (DEL PRIORE, 1990, p. 02).

O cotidiano a bordo das embarcações das armadas da Índia era sempre duro para os homens e pior ainda para as mulheres. Além de terem de enfrentar os mesmos obstáculos encarados pelos homens, as mulheres tinham ainda de enfrentar o assédio da tripulação quase exclusivamente masculina, composta em sua maioria por homens de caráter e índole duvidosos. Para termos uma idéia da proporção entre homens e mulheres a bordo, "um navio da Índia que levava oitocentos, ou mais, homens, transportaria dez ou quinze mulheres; por vezes não levaria nenhuma" (BOXER, 1977, p. 84), o que conferia uma proporção de cerca de pouco mais de cinqüenta homens para cada mulher embarcada.

Nestas condições, defender a virtude máxima da época, ou seja virgindade, ou ainda a castidade, para uma mulher do povo, que não se encontrava protegida por sua condição social, era praticamente impossível, e mesmo para as mulheres de condição social mais elevada constituía um enorme desafio. Exatamente por este motivo, "a Coroa Portuguesa" muitas "vezes desencorajou as mulheres a acompanhar, ou juntar-se, aos maridos na Ásia ou África, embora fosse mais complacente no que dizia respeito ao Brasil" (BOXER, 1977, p. 34), uma vez que era muito mais fácil controlar o apetite sexual a bordo por quatro semanas do que por vários meses.

"Sem a ajuda da Coroa, o emigrante comum não tinha possibilidade de fazer transportar a mulher e/ ou as filhas para a Índia. Os monarcas portugueses, sempre afligidos por dificuldades, também não podiam garantir ajuda em larga escala" (BOXER, 1977, p. 81-82). De acordo com o temperamento português descrito pelos viajantes que passaram pelo país, os portugueses, quer fossem ricos ou pobres, eram sempre 
"altivos, orgulhosos e arrogantes"31, e principalmente possessivos com relação a suas esposas, filhas ou irmãs, de forma que não admitiam o risco de vê-las violadas a bordo das embarcações da Carreira da Índia.

Para termos uma idéia da possessividade do homem português com relação a suas mulheres, é extremamente ilustrativo o caso descrito pelo viajante Charles Fréderic de Merveilleux, de "um oficial de justiça de Lisboa", que mais tarde ocuparia uma das "mais elevadas posições", que "tendo visto que sua mulher correspondia urbanamente ao cumprimento que um estrangeiro lhe fazia ao passar na rua, subiu a casa, muniu-se de um martelo e de um grande prego, derrubou a esposa e, a grandes marteladas, enterrou-lhe o prego no pescoço, deixando-a assim pregada ao solho do quarto. Fechou a porta e saiu tranqüilamente à procura do sogro, a quem narrou a bela acção que acabava de praticar, entregando-lhe a chave do quarto onde deixara a esposa encerrada para que ele fosse socorrer a filha e a levasse para sua casa, se assim entendesse dever fazê-lo, no caso de a encontrar com vida. O pai aterrorizado correu em socorro da filha que encontrou nas vascas da morte, embora não tivesse perdido muito sangue. Fê-la tratar e a senhora veio a curar-se da ferida, tendo jurado a seu pai que toda a sua falta consistia em ter correspondido à saudação do estrangeiro, que ela, aliás, nunca antes havia visto e que sua consciência não a acusava de nada mais. $O$ pai não pôs em dúvida que fosse este o facto que bastou para despertar os ciúmes do marido e foi-lhe falar. O homem que já caíra em si, considerando a crueldade e injustiça do seu procedimento, confessou que sua mulher nunca lhe havia da-

31 "Carta escrita de Lisboa pelo viajante César de Saussure, datada de 28 de janeiro de 1730" In: CHAVES, 1989, p. 272.

32 "Memórias instrutivas sobre Portugal, por Charles Fréderic de Merveilleux, 1723-1726” In: CHAVES, 1989, p. 225.

${ }^{33}$ Idem, Ibid, p. 227 do ocasião à menor suspeita quanto a fidelidade, chorou e foi ajoelhar-se aos pés da esposa, que o recebeu com bondade e lhe perdou. Depois" tornaram a viver "juntos, e bem, e chegaram um e outro a uma velhice feliz"32.

Caso tipicamente ilustrativo da possessividade portuguesa em pleno no século XVIII, este relato nos faz pensar que o ciúme do homem português em épocas anteriores, tal como no século XVI e XVII, teria provavelmente sido muito mais agudo e trágico. Quer por ciúmes, excesso de zelo, ou falta de recursos para levar a esposa e filhas junto consigo para a Índia, apesar de "portugueses não" quererem "perder de vista as esposas" 33 , terminavam deixando-as em Portugal. E não obstante conservarem "suas mulheres fechadas a sete chaves e sujeitas a dura escravidão"34, ao tentar evitar o que na sua concepção seria o pior, acabavam deixando suas esposas e filhas entregues aos sedutores de plantão que faziam questão "de consolar algumas senhoras afligidas com o afastamento de seus maridos" 35 . Mesmo quando deixavam suas mulheres aos cuidados dos "padres confessores", não podiam evitar os "episódios escandalosos que os frades (ofereciam) quotidianamente e" de pleno "conhecimento público" ${ }^{36}$.

Entre um povo de sangue quente que não respeitava nem mesmo os conventos de freiras, "casas bastante livres para a galanteria" ${ }^{\prime 3}$, o temor dos portugueses em levar a bordo das embarcações da Carreira da Índia suas mulheres não era de todo infundado, em meio a um grande contingente de homens "velhacos, traiçoeiros, (e) desonestos" ${ }^{\prime 38}$, como no resto da

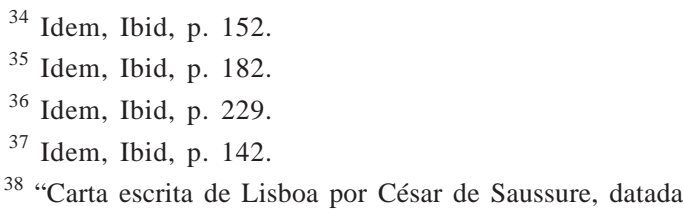
de 28 de janeiro de 1730" In: CHAVES, 1989, p. 272. 
Europa, as violações coletivas eram bastante comuns. Em seu estudo sobre a prostituição na Idade Média, Jacques Rossiaud, assistido e apoiado por Georges Duby, mostra que eram bastantes comuns nas cidades medievais as violações de mulheres "de 15 até 33 anos" (ROSSIAUD, 1986, p. 43), cometidas por grupos de homens mal intencionados que ficavam dias à espreita a procura de uma oportunidade ideal para praticarem o crime. Em geral estes crimes terminavam não sendo punidos, e ao contrário do que se poderia supor, às vítimas acabavam sendo conduzidas pela justiça a um bordel ou casa de banho público, sendo forçadas a passar o resto de seus dias como prostitutas a atender como clientes seus violadores que haviam saído impunes.

De fato, violações só eram punidas se "as vítimas tivessem de 12 a 14 anos". Neste caso a punição era sempre exemplar e as vítimas em geral reintegradas à sociedade. Levando em conta a impunidade observada em terra, tudo leva a crer que em mar o mesmo se repetisse, a certeza da impunidade encorajava as violações, além disto o medo de serem repudiadas e segregadas pela sociedade fazia com que as mulheres tentassem sempre ocultar o fato de terem sido violadas. Solteira, caso fosse violada, a vítima "era depreciada no mercado matrimonial", casada, "as vezes era abandonada pelo marido", "a vítima quase sempre difamada", caso tornasse pública a violência por que havia passado, tinha multiplicadas as dificuldades 'para sua reinserção social”' (ROSSIAUD, 1989, p. 43-44).

Como se não bastasse o risco de serem violadas por seus próprios compatriotas, as mulheres corriam sempre o risco de serem aprisionadas por corsários mouros, e curiosamente, "muito embora" tanto os corsários como os portugueses "sejam responsáveis por atrocidades", neste tocante "a reputação dos Islamitas é melhor que a dos Cristãos. A violação de mulheres era profundamente repugnante dentro das severas regras de guerra tribal, em muitas, se não em todas, as áreas do mundo islâmico. Do lado cristão, tais inibições raramente existiram. João Carvalho Mascarenhas, soldado português muito viajado, feito prisioneiro por corsários argelinos em 1621, servindo depois vários anos como remador escravo nas galés, observou que os corsários mantinham sempre as cativas segregadas, não autorizando relações sexuais a bordo" (BOXER, 1977, p. 19).

Embora o tratamento dispensado às mulheres por parte dos mouros fosse um pouco melhor, não faltaram também exemplos de violência contra mulheres por parte destes, como por exemplo "quando Santa Cruz do Cabo foi finalmente tomada de assalto pelo Xerife de Sus, (e) entre os prisioneiros estava o capitão da fortaleza, D. Goterre de Monroi, gravemente ferido, e a sua bela filha, D. Mécia, que tinha dado à luz recentemente e cujo marido acabava de ser morto". Dona Mécia "foi levada para o harém do vencedor, tornando-se depois sua esposa, após lhe ter dado um filho" acabou morrendo. Embora Boxer defenda a tese de que "as mulheres, de ambos os lados", estarem sempre "prontas a deixarem-se converter quando aprisionadas, mais por persuasão gradual do que devido a maus tratos físicos", este tipo de tratamento só era reservado aos bem nascidos, "as pessoas comuns eram convertidas à força, ou reduzidas, sem mais delongas, à escravidão" (BOXER, 1977, p. 17-18) pura e simplesmente.

Dentro deste contexto torna-se extremamente significativo o fato de "pelo menos nos séculos XVII e XVIII, nenhuma esposa de vice-rei ou governadorgeral" ter acompanhado "o marido à Índia, de 1549 a 1750" (BOXER, 1977, p. 82). Examinando a proporção de mulheres em relação "ao número de homens normalmente embarcados" fica fácil entender que as mesmas "se tornassem focos de tensão pela sua presença num meio de grande predominância masculina, gerando por decorrência problemas de natureza disciplinar, que se procuravam resolver as mais das vezes pelo isolamento puro e simples ou, mais drasticamente, desembarcando-as na primeira oportuni- 
dade" (DOMINGUES, p. 204), isto é claro, principalmente no caso das chamadas clandestinas.

Não era o fato de haver mulheres a bordo que causava alvoroço entre os homens, e sim o fato de serem escassas. Notando a raiz do problema, ao contrário dos portugueses, desde o início da colonização da América os espanhóis procuraram fixar o embarque de pelo menos "uma mulher para cada dez homens", inicialmente enviando "ciganas condenadas por assassinato" e mais tarde exigindo que "todos os emigrantes partissem acompanhados por suas esposas". Muito embora esta exigência, fixada já em 1501, fizesse com que muitos homens embarcassem com "falsas esposas", na verdade "meretrizes", o sistema espanhol conseguiu garantir que entre "1493 e 1559" fossem embarcadas cerca de "3 a 10\%" de mulheres dentro de um total de "28.019 passageiros", e que do total de passageiros embarcados entre "1540 e 1575 ", "23\%" fossem mulheres, isto sem contar o "considerável número de passageiras clandestinas" ${ }^{39}$, não obstante entre "1509 e 1533, 37\% das passageiras embarcadas declararem-se viúvas ou celibatárias" (DELAMARRE, 1992, p. 122-127).

Apesar de as mulheres, "como acontecia em todas as regiões tropicais e subtropicais", mostrarem-se "mais resistentes às doenças e mais capazes de atingir idades" mais "avançadas do que os homens" (BOXER, 1977, p. 103-104), a Coroa portuguesa não só desencorajou a ida de mulheres para a Índia, como "também legislou contra a ida de raparigas solteiras para as Índias, a não ser como membros da família de um emigrante, ou de um funcionário colocado nas colônias, ou de criadas empregadas por estes", embora "esta lei" fosse "freqüentemente contornada com facilidade, pois nada obstava que "o chefe de família e a esposa" pudessem "levar consigo, não só as filhas,

${ }^{39}$ Idem, Ibid, p. 125 como também as sobrinhas ou as primas", ou ainda "que uma rapariga com recursos, à caça de marido nas colônias, se fizesse passar por familiar ou criada de um chefe de família complacente" (BOXER, 1977, p. 47-48).

Devido à raridade de mulheres embarcadas na Carreira da Índia, "as mulheres brancas" terminaram se tornando "prêmio cobiçado" nas feitorias da África e Ásia. Quando a disputa pelas mulheres brancas começou a afetar o bom relacionamento dos soldados e funcionários das feitorias portuguesas na África, a Coroa procurou contornar o problema fornecendo "uma negra, declaradamente para a procriação", "a cada homem solteiro", sendo a cerimônia do "casamento (..) facultativa" (BOXER, 1977, 21-29), enquanto na Ásia os próprios interessados procuraram "esposas Chinesas, ou mais freqüentemente a usar as Chinesas como concubinas e criadas contratadas" (BOXER, 1977, p. 106).

No entanto, apesar das soluções provisórias, a disputa por mulheres brancas continuou a constituir um grande problema interno, forçando a Coroa a adotar o sistema de "Orfãs del Rei", considerando como órfãs crianças que haviam perdido "os progenitores, ambos ou um só, especialmente se o falecido fosse o pai", a Coroa recolhia as órfãs de "14" a "30 anos" nos "orfanatos de Lisboa e Porto", custeando sua ida para a Índia quando atingiam a idade de casar. "O primeiro contingente deixou Lisboa em 1545, tendo o sistema funcionado de forma intermitente, até o século XVIII", e tendo sido enviado o "maior contingente" em "1560", num total "de cinqüienta e quatro" (BOXER, 1977, p. 83-88) órfãs enviadas num período de um ano.

O sistema de órfãs do Rei, além de custear a ida de mulheres para a Índia, procurava incentivar o matrimônio das mesmas, oferecendo "a cada rapariga (...) um dote" e "um emprego pouco importante no funcionalismo para o homem que a desposasse". Embora o sistema tenha atingido um considerável 
êxito, não conseguiu suprir a falta de mulheres na Carreira da Índia, isto talvez pelo fato de muitas das mulheres embarcadas como órfãs serem na verdade prostitutas, pois eram também admitidas nos orfanatos "mulheres impudicas lá colocadas pelos magistrados". Provavelmente por este motivo "as damas de Goa sempre tiveram má fama, sendo acusadas de excesso de orgulho, indolência e imoralidade" (BOXER, 1977, 29-106), sob a justificativa de que o clima quente tornava propicia a promiscuidade.

Desde o início da Carreira da Índia, as prostitutas, classificadas sob a categoria em que haviam embarcado, ou seja clandestinas trazidas por tripulantes ou passageiros, em um país em que era "quase uma vergonha recusar visita aos bordéis, especialmente se o convite" tivesse sido "feito por um fidalgo" ${ }^{40}$, eram muito comuns a bordo das embarcações portuguesas. Como nas Colônias, "a prostituição, embora aparentemente transgressora, constituía-se numa prática a serviço da ordem sócio espiritual" (DEL PRIORE, 1992, p. 22). No entanto quando uma clandestina era encontrada a bordo, na maior parte das vezes os Padres presentes exigiam que fosse desembarcada no porto mais próximo, ou que fosse encerrada e isolada do resto da tripulação, não obstante em outros casos terem sido admitidas a bordo pagando sua viagem com trabalho.

A presença de prostitutas na Carreira da Índia, apesar de por vezes acalmar os ânimos, contaminava constantemente os que com elas se relacionavam com doenças venéreas, pois na época, mesmo na metrópole, ter contato com prostitutas representava um grande "perigo", a medida que "raramente" deixava-se de ser "prendado com certas lembranças de Vénus suficientes para (...) amargurarem e fazerem arrepender da

\footnotetext{
40 "Memórias instrutivas sobre Portugal, por Charles Fréderic de Merveilleux, 1723-1726” In: CHAVES, 1989, p. 184.
}

imprudência", caso o homem contaminado não se tratasse "imediatamente" podia-se considerar "um homem perdido" ${ }^{41}$, e estava justamente neste ponto o grande problema, afinal não havia como se tratar em pleno alto mar e na quase certa ausência de um médico.

Talvez por este motivo, mesmo depois que o número de mulheres a bordo começou a aumentar, as violações continuaram a ser freqüentes. Prova disto é o curioso caso da "freira do século XVII", que "morreu com reputação de santidade", que sendo de origem asiática "foi raptada por piratas Portugueses de baixa extração" para ser vendida como escrava ao "vice-rei do México", e que teve de ser "vestida de rapaz para" que fosse protegida "de atenções indesejáveis por parte dos marinheiros, famintos de mulher", afim de poder fazer a "viagem de sete ou oito meses através do Pacífico" (BOXER, 1977, p. 51) em segurança.

Além das esposas, filhas e parentes de imigrantes, das religiosas, das órfãs do Rei, e das prostitutas, uma outra categoria de mulheres também fez parte das passageiras embarcadas com destino à Índia. Foram as "criminosas" condenadas, tais como os homens, "a cumprir pena" (BOXER, 1977, p. 33) como degradadas. Em geral condenavam-se mulheres responsáveis por crimes graves como assassinato a penas leves de cinco ou dez anos de degredo na Índia, ao mesmo tempo em que crimes como roubo, vadiagem, ou o simples fato de ser cigana, eram punidos com o degredo perpétuo.

Os espanhóis foram pioneiros na utilização do envio de degredadas para suas Colônias, enviando o primeiro contingente "de ciganas condenadas por assassinato" para as "novas Índias" em "janeiro de 1498 ". Devemos fazer notar aqui que apesar da seme-

${ }^{41}$ Idem, Ibid, p. 135. 
lhança com o sistema português, ao contrário deste, para quem o degredo representava uma pena a ser cumprida, as degredadas espanholas não eram enviadas a cumprir uma pena, e sim "perdoadas com a condição de embarcarem" (DELAMARRE, 1992, p. 122) para as Colônias.

Apesar do reduzido número de mulheres presentes na Carreira da Índia, e da mentalidade masculina portuguesa considerar que "arrumar em condições uma arca de roupa era a mais elevada tarefa intelectual de que uma mulher era capaz” (BOXER, 1977, p. 37), as mulheres tiveram participação ativa e muitas vezes heróica na empreitada marítima rumo a Índia. Não obstante os "textos bíblicos e jurídicos" (darem) caução à menoridade da mulher, e a igreja (valer-se) da eloquência dos sermões" para traçar uma imagem de fragilidade e astúcia "da mulher-diaba", bem como "os médicos (endossarem) a idéia da inferioridade estrutural da mulher" (DEL PRIORE, 1990, p. 37), expostas aos mesmos obstáculos enfrentados pelos homens, muitas delas terminaram se mostrando muito mais resistentes que seus pares do sexo oposto.

A bordo das embarcações portuguesas não faltaram exemplos como o de "D. Maria Úrsula de Abreu e Lencastre", que nascida "no Rio de Janeiro", disfarçada de homem "alistou-se, sob o nome de Baltasar do Couto Cardoso, como grumete num navio destinado a Lisboa", embarcando depois "para a Índia no último ano do século XVII, distinguindo-se em numerosas batalhas durante os catorze anos seguintes, sem que o seu verdadeiro sexo fosse descoberto", e terminando por salvar "o seu capitão, em perigo eminente de ser morto ou capturado pelo inimigo", sendo por isso "ferida com gravidade, o que levou à descoberta do seu sexo". Mais tarde, este curioso caso, teve por desfeixo o casamento entre ela e seu capitão, seguido pelo nascimento de "um filho" e pela "doação", em "reconhecimento" dos serviços prestados à Coroa por D. Maria, de "dois palmares em Chaul, na Província do Norte, nos quais, podemos admitir, (ela) viveu feliz em companhia do marido até ao fim dos seus dias" (BOXER, 1977, p. 100-101).

Mesmo nas feitorias, as mulheres mostravam-se com freqüência extremamente resistentes, combatendo "nas muralhas, ombro a ombro com os homens. Os cronistas deixaram-nos relatos, onde os feitos destas amazonas de circunstâncias são recordados com admiração. Assim, quando Cabo da Gué quase foi tomada de surpresa, em 1533, uma mulher possante, grávida de seis meses, chegou transportando às costas grandes pedras que dois homens mal podiam erguer. Ela manejava-as como se nada fossem. Pois nem mesmo esta hercúlea actividade evitou que, três meses depois, desse à luz uma criança normal". "Em outra ocasião, quando Arzila parecia prestes a cair perante um furioso ataque dos Mouros, o baixo moral da guarnição foi reanimado por uma das filhas do governador, mulher casada que estava então prenhe e com a barriga à boca de uma filha que logo pariu. Na companhia da mãe e das irmãs, envergonhou os soldados acobardados para que voltassem aos seus postos e empunhou uma besta com a qual atirou aos Mouros" (BOXER, 1977, p. 17).

Oprimidas pelo cotidiano duro da Carreira da Índia, pelos seus próprios compatriotas, e pela mentalidade da época, as mulheres souberam ser duras, e provaram ser capazes de, como qualquer homem, enfrentar as adversidades do dia a dia no mar de cabeça erguida, mostrando a valentia e resistência necessárias.

\section{VI - Conclusão}

Através da descrição de alguns aspectos do cotidiano da Carreira da Índia nos séculos XVI e XVII, pudemos constatar certos problemas enfrentados pelos navegantes portugueses que contribuíram para o escasseamento de voluntários, e portanto de uma mão-de-obra qualificada, para tripular as embarcações desta Carreira, enquanto por sua vez o número 
de voluntários para a Carreira do Brasil se tornou cada vez mais crescente.

Obviamente, na falta de voluntários a Coroa Portuguesa passou a fazer um uso maior dos chamados degredados enquanto mão de obra, o que ocasionou uma queda no padrão de qualificação profissional dos tripulantes da Carreira da Índia, e consequentemente um aumento no número de naufrágios, uma vez que contando com uma tripulação cada vez mais despreparada e de caráter ainda mais duvidoso, as embarcações portuguesas da Índia ficavam mais expostas aos perigos do mar.

Com o aumento do número de naufrágios, investir na Carreira da Índia se tornou cada vez mais arriscado. Por este motivo, entre outros, tais como a queda do preço das especiarias e a crescente concor-

\section{Bibliografia:}

ALBUQUERQUE, Luís de (org.). Relações da Carreira da Índia. Lisboa, Alfa, 1989.

AZEVEDO, J. Lúcio de. Épocas de Portugal Econômico. $4^{\mathrm{a}}$. Edição. Lisboa, Clássica Editora, 1988.

BARCELlOS, Christiano (org.). Construções de Naus em Lisboa e Goa para a Carreira da Índia no começo do século XVII. Lisboa, Separata da Biblioteca da Marinha Portuguesa, 1988.

BOXER, Charles Ralph. A mulher na expansão ultramarina ibérica. Lisboa, Livros Horizonte, 1977.

BRAUDEL, Fernand. O mediterrâneo e o mundo mediterrânico na época de Felipe II. Lisboa, Martins Fontes, 1983.

BRITO, Bernardo Gomes de (org.). História TrágicoMarítima. Lisboa, Edições Afrodite, 1971, fac-símile da edição original de 1735.

CHAVES, Castelo Branco (tradução, prefácio, e notas). $O$ Portugal de D. João V. visto por três forasteiros. Lisboa, Biblioteca Nacional, 1989.

DELAMARRE, Catherine \& SALLARD, Bertrand. La Femme au temps des conquistadores. Paris, Stock/Pernoud, 1992.

DEL PRIORE, Mary. A mulher na História do Brasil. São Paulo, Contexto, 1992. rência holandesa e inglesa, a partir da segunda metade do século XVII, o número de embarcações enviadas pela Coroa Portuguesa para a Índia cai a números insignificantes, enquanto por sua vez os navios enviados ao Brasil tem um número cada vez maior.

Como já dissemos a questão é muito mais complexa. No entanto não se pode deixar de admitir que o cotidiano da Carreira da Índia foi um fator, entre outros, do abandono gradual da rota de especiarias via Atlântico e Índico, em benefício da exploração colonial do Brasil, à medida que a Carreira do Brasil representava um tempo menor de percurso, portanto um retorno financeiro mais rápido, menos riscos a correr durante a viagem, e um padrão de qualidade de vida melhor para seus tripulantes e passageiros, em oposição à Carreira da Índia, sinônimo de morte certa, e prejuízo financeiro.

DEL PRIORE, Mary. Ao sul do corpo: condição feminina, maternidade e mentalidades no Brasil Colônia. Tese de doutoramento apresentada ao Depto. de História da FFLCH-USP, sob a orientação da Profa. Dra. Maria Luiza Marcílio; São Paulo, 1990.

DOMINGUES, Francisco Contente \& GUERREIRO, Inácio. "A vida a bordo na Carreira da Índia (século XVI)". Revista da Universidade de Coimbra, Lisboa, Separata da Biblioteca Central da Marinha Portuguesa, s.d.

FONSECA, Quirino da. A caravela portuguesa e a prioridade técnica das navegações. Lisboa, Ministério da Marinha Portuguesa, 1978.

MICELI, Paulo. O Ponto onde estamos: viagens e viajantes na história da expansão e da conquista. São Paulo, Scritta, 1994.

MORENO, Humberto Baquero. História de Portugal Medievo: político e institucional (apêndice). Lisboa, Universidade Aberta, 1995.

RÊGO, Raul (leitura e prefácio). $O$ último regimento e o regimento da economia da inquisição de Goa. Lisboa, Biblioteca Nacional, 1983.

ROSSIAUD, Jacques. La Prostituición en el Medievo. 
Barcelona, Ariel, 1986.

SARAIVA, José Hermano. História Concisa de Portugal. 10ª . Edição. Lisboa, Publicações Europa-América, 1995. SÉRGIO, Antônio (organização e notas). Naufrágio $e$
Combates no Mar. Lisboa, Livros Horizontes, 1958.

VAINFAS, Ronald. "Homoerotismo feminino e o Santo Ofício", In: DEL PRIORE, Mary (org.). História das Mulheres no Brasil. São Paulo, Contexto/Unesp, 1997, p. 113-139. 